\title{
Tourism Potential Identification in Optimizing the Pasir Padi Beach Development Strategy
}

\author{
Nanang Wahyudin*, Sandy Pratama, Muhammad Faisal Akbar \\ Faculty of Economics \\ Universitas Bangka Belitung \\ Belitung, Indonesia \\ *nanang.w19@gmail.com
}

\begin{abstract}
The objective of this research is to identify the tourism potential development of Pasir Padi Beach and offer a program of development focusing on improving the tourism attraction based on the tourists' judgment. The method used for this research is mixed-methods; qualitative analysis using IPA (Importance Performance Analysis) to identify the conditions of the research variables as well as every indicator supported by gap analysis and descriptive quantitative analysis in order to elucidate the strength and weakness by means of SPSS analysis tool version 22. Regarding to the number of respondents, 60 tourists are selected through non-probability sampling and Convenience Sampling. The result shows that there are one variable included in the main priority to be improved, and seven indicators included in the main priority to be improved and developed. Thus, the research proves that the attraction variable and sea water quality indicator, transportation availability, shower and clean water facility, quantity and quality of the toilet, rubbish bin availability, cleanliness quality, and environment awareness are the main prioritized indicators and variables to be improved and developed.
\end{abstract}

Keywords-development strategy, importance performance analysis, tourism, beach

\section{INTRODUCTION}

Bangka Belitung Province is well-known as the biggest tin producer in Indonesia and even the second biggest tin producer in the world [1]. Since hundreds years ago, tin has been giving a big contribution to the Bangka Belitung Island economy, in which the local people depend on their livelihood. Nevertheless, they realize that this unrenewable resource will be used up, so that they must be ready to change their livelihood. Although there is still a little number of farmers, but the number keeps decreasing. The government should also prepare to shift the people's livelihood to other sectors and develop other island's potentials. Bangka Belitung has many beautiful beach potentials. Promoted by Laskar Pelangi movie this island becomes more popular and therefore it has a new strategic sector that is tourism. This sector is recently known in national scope, but its development is still poor.

Tourism development is generally directed as the prioritized sector in order to support economy growth, regional income and empower people's economy, extend job vacancy and business opportunity as well as extend product marketing. Those efforts have the final objective, which is to improve the people's welfare. This tourism development is an integrated well-prepared program, which aims to achieve the optimal benefit for the people [2].
This beach tourism development should be supported by many parties including people, stakeholders, regional government as well as local organization. The well-developed tourism can be a good alternative to increase the Pangkalpinang economy and increase the local people's income.

Pangkalpinang is the capital city of Bangka Belitung Province whose location is very strategic as the main gate for the surrounding region's economy. Pangkalpinang is the center of economy for Bangka Belitung. As the center of business, it also has variety of tourism object, one of which is Padi Beach. This beach faces to Southern China Sea directly and has 100$300 \mathrm{~m}$ of coastal line. With calm waves, white and solid sand, this Padi Beach area is a very potential tourism in Pangkalpinang city. A lot of visitors coming from out of regions and overseas, from both Depati Amir Airport and Pangkalbalam Port can visit this beach [3].

Padi Beach is only $7 \mathrm{~km}$ from the downtown. This can be the most influential consideration for visitors coming to Pangkalpinang. However, the existing potentials have not been developed optimally. Thus, the tourism is regarded developed slowly.

The tourism sector in Pangkalpinang during 2017 reached its peak season on December that was 22.776 visitors consisting of 22,675 domestic visitors and 101 foreign visitors. As the lowest visit was on January that was only 13,000 visitors. Domestic visitors tend to be more than foreign visitors. As described on the Table 1, the number of domestic visitors increases every year.

TABLE I. NUMBER OF FOREIGN AND DOMESTIC VISITORS VISITING TO PANGKALPINANG

\begin{tabular}{|l|l|l|c|}
\hline \multicolumn{1}{|c|}{ Month } & \multicolumn{1}{c|}{$\begin{array}{c}\text { Foreign } \\
\text { Visitor }\end{array}$} & $\begin{array}{c}\text { Domestic } \\
\text { Visitor }\end{array}$ & Total \\
\hline \multicolumn{1}{|c|}{$(\mathbf{1})$} & \multicolumn{1}{c|}{$(\mathbf{2})$} & \multicolumn{1}{c|}{$(3)$} & $(\mathbf{4})$ \\
\hline January & 57 & 12943 & 13000 \\
\hline February & 309 & 13226 & 13535 \\
\hline March & 256 & 18052 & 18308 \\
\hline April & 183 & 19624 & 19807 \\
\hline May & 85 & 17998 & 18083 \\
\hline June & 72 & 14231 & 14303 \\
\hline July & 100 & 16985 & 17085 \\
\hline August & 125 & 17938 & 18063 \\
\hline September & 183 & 19545 & 19728 \\
\hline October & 75 & 19165 & 19240 \\
\hline November & 117 & 20197 & 20314 \\
\hline December & 101 & 22675 & 22776 \\
\hline
\end{tabular}


Table 1. Cont

\begin{tabular}{|l|l|l|l|}
\hline $2017 \quad$ Total & 1663 & 212579 & 214242 \\
\hline 2016 & 1009 & 196999 & 198008 \\
\hline 2015 & 1052 & 192206 & 193258 \\
\hline \multicolumn{4}{|c|}{ Source: BPS Pangkalpinang, 2018 } \\
\hline
\end{tabular}

Based on the data table 1 above, the number of foreign visitors is far less than the number of visitor to the next city that is Palembang with 10,683 in 2016. As for the star hotels occupancy rate in Pangkalpinang tends to decrease. Even one of the main tourism object in Pangkalpinang that is Pasir Padi Beach is not well-developed. The local people awareness is still low and there is no prioritized development program. Moreover, the poor tourism promotion is still a problem that remains unsolved. Therefore, a proper development strategy can be the main hope in developing Padi Beach tourism. Thus, this research is important to measure the priority up to the level of indicators.

\section{METHODS}

This research was carried out in Pangkalpinang with the main object Pasir Padi Beach. It was done from March to August 2019. The sampling technique used in this research is non-probability sampling with Convenience Sampling method [4]. As for the samples, the 60 respondents are involved. This research uses primary and secondary data. The researchers tried to combine quantitative and qualitative method, which is later called as combined research. The concept of the method can be seen in the following diagram (figure 1).

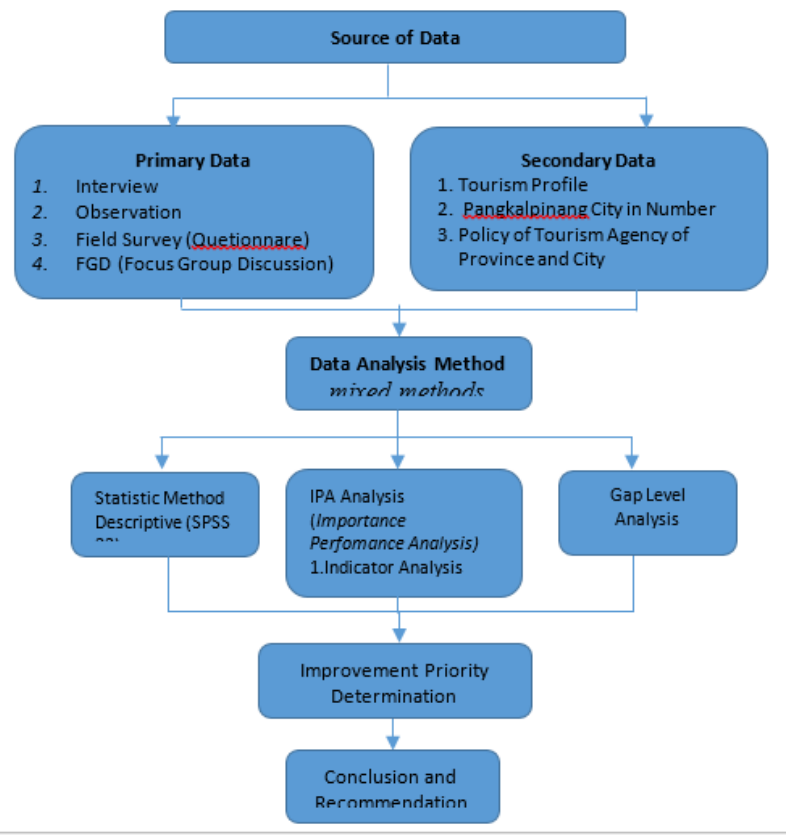

Fig. 1. Diagram of research methodology concept.

The mixed method is one of methods that combine quantitative and qualitative method altogether in a research in order to get more comprehensive valid reliable and objective data [5]. The analysis begins with descriptive analysis to describe the general condition of Padi Pasir Beach with SPSS analysis version 22. While to examine potential as well as weakness in details, we use IPA (Importance Performance Analysis) analysis with gap level analysis.
The analysis technique used in this research is IPA Analysis to find out the level of customer satisfaction focusing on the importance attributes and performance evaluation, [6]. This research begins with identifying visitors through identifying importance or expectation level and performance or satisfaction level using IPA method. The result of this analysis is used as reference to identify potentials and conditions of Padi Pasir Beach that will be analyzed later in order to find out the gap between the expectancy and reality felt by the visitors.

\section{RESULTS}

\section{A. General Description of Respondents in Padi Pasir Beach}

The general description of respondents in Padi Beach should be described in details to support the result of data analysis. As for the respondent's description based on the field survey, there is no significant difference in number of visitors based on gender. However, the number male visitors are more than the number of female visitors. In terms of age, $41 \%$ of them are in the age of 24 to 32 years old, meaning they are in the late adolescence and the early stage of maturity. Regarding with occupation, $66 \%$ of them are workers and $11 \%$ of them are students. While in the education level, $40 \%$ of them are Bachelor Degree graduates and 37\% of them are Senior High School graduates.

In addition to the respondents' profile, visit intensity, Bangka Belitung Island image, visit motive, and visit contingent should also be assessed. Based on the field survey, the authors can deduce that most visitors or $33 \%$ have intensity more than 6 visits times, meaning they have revisited minimally once in a month. Most of them are domestic visitors from Pangkalpinang and other sub-districts nearby in Bangka Belitung. They choose Padi Beach for spending their leisure time. The next visit intensity is $1-2$ times; $28 \%$ of visitors who have this intensity generally are from national domestic, especially Jakarta, Palembang and Bandung. They are categorized as new domestic visitors.

As for the visit motive to the Padi Beach, $76.7 \%$ state that they only want to spend their leisure time. This means they choose the place not only due to the facilities but also due to the accessible distance. While the motive of enjoying the object and the atmosphere in Padi Beach is about 23.3\%.

Regarding to visitor origin, the ones who are from out of Bangka Belitung is about 36.7\%. It means Pasir Padi Beach has been a national object. Some of the reasons are because it is near from Pangkalpinang City. As for the visitors from the city is about $35 \%$. This figure shows that the people of Pangkalpinang are interested in the object and choose it as their vacation destination. While the visitor from other districts is about 28\%, meaning the visitors of Pasir Padi Beach are diverse.

However, the image of Bangka Belitung Island is still wellknown as tin mining area. Since $51.7 \%$ of visitors state that they know this island due to its tin mining, and $36.7 \%$ of them know it as a new tourism object, which now becomes the main regional object and shifts the image of tin mining.

\section{B. IPA Analysis}

According Ivan Saver, Importance-performance analysis (IPA) is considered a useful tool in examining customer 
satisfaction and management strategies [7]. This technique can help tourism stakeholders in diagnosing underlying deficiencies and setting priorities in tourism development. This analysis is also used in the research carried out by Tantri Wijayanti [6], Ivan Ka Wai Lai and Michael Hitchcock [8]. This IPA analysis begins with every indicator analysis and moves to research variable. The results can be seen as follow figure 2:

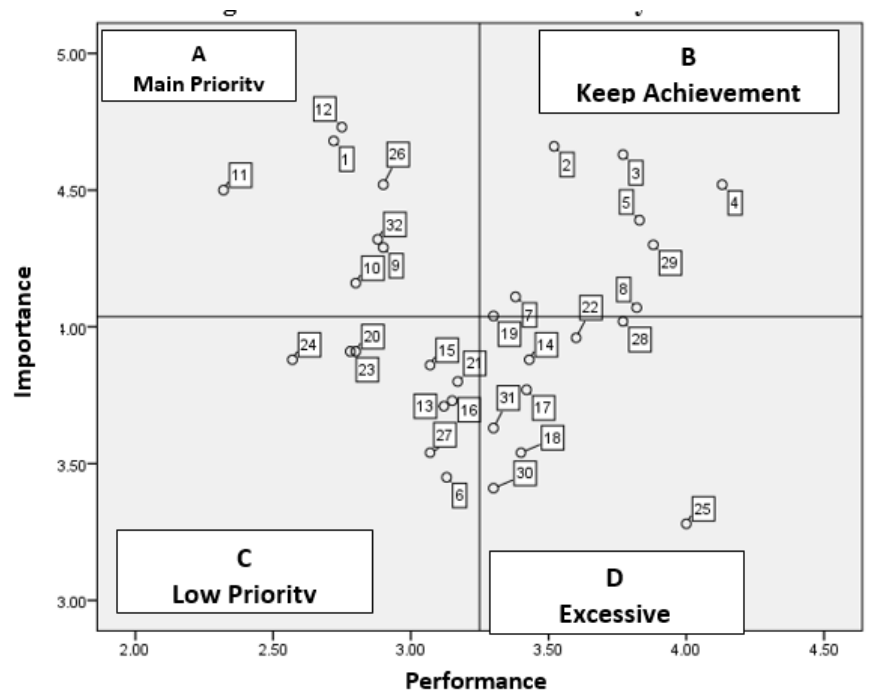

Source: Data processed in 2019

Fig. 2. Result of indicator analysis

The following is the description of the results using SPSS 22 in mapping indicator of variables:

- A: Quadrant A shows the main priority of improvement. The indicators in this quadrant shows the very important factors and attributes. However, the reality is far beyond the visitors' expectancy. It means the object management is not able to manage it to meet their satisfaction. Thus the visitors are not satisfactory. Indicator 1 (quality of water); the water is not clear enough, many rubbish and used mining tailing make the visitors not satisfactory. However, the beauty of the beach is already good. Indicator 9 (public transportation availability to the object); there is no direct public transportation to Padi Beach. However, the online-based transportation is very helpful in accommodating the visitors to reach the destination. Indicator 10 (clean water and shower room); many visitors complain the facility and the water that are not clean. Indicator 11 (quality and quantity of toilet); the quantity of toilet is still limited. There are only some, which are located in the north, even the cleanliness is still poor. Indicator 12 (rubbish bin availability); generally, the rubbish bins are already available in several spots, though the number is still limited and not accessible from the coastal line. Indicator 26 (cleanliness quality); generally, this quality in the coastal line is still poor. Indicator 32 (people's awareness to the encironment); their awareness is still low as indicated by many rubbish around the beach.

- B: This quadrant shows the satisfactory attraction and services. Therefore, they should be maintained well. Indicator 2 (beauty and quality of sand); the beauty of the beach lies on leafy plantation. This makes the visitors satisfied. Indicator 3 (nature panorama); the visitors claim that the beach panorama is very amazing, with relatively calm waves and white clear sand. Indicator 4 (wide coastal line); the visitors feel satisfied with the wide coastal line, so that they can benefit it for leisure activities. Indicator 5 (wave type); the waves are relatively calm making the visitors can relax on the seashore while watching their kids playing water. Indicator 7 (attraction or event); motor cross event, and fishing competition are some of attractions that can attract more visitors. Indicator 8 (child playground); the playground makes the visitors more satisfied, especially the domestic visitors who bring their family. Indicator 29 (hospitality); the local people's hospitality makes the visitors feel satisfied and comfortable.

- C: This quadrant (low priority) shows relatively stagnant management and poor facilities and the visitors claim it not satisfactory, therefore they need improvement. Indicator 6 (fishermen's boats); the fishermen's boats do not disturb the visitors, even they feel amazed and curious with them. Indicator 13 (electricity and lighting); there are some electricity facilities in several spots and later the management will add them. Indicator 15 (playing facility); though the local visitors think this facility is well-accommodated, but the national visitors are not really interested in it. Indicator 16 (home stay); this facility is not really urgent, however as the promotion develops, then this facility will be important. Indicator 20 (information center); the information office is available, though it does not function well. Indicator 21 (security service); there is security office but the visitors claim that it is lack of personnel. Indicator 23 (information source). Indicator 24 (brochure about the object); there is no source information such as brochure. Indicator 27 (management service); the visitors claim it is still poor.

- D: This quadrant shows a number of non-influential factors with excessive execution. They are not really important but satisfactory. Indicator 14 (small shops/restaurant). Indicator 17 (telecommunication or internet quality). Indicator 18 (hotel and café). Indicator 19 (parking area). Indicator 25 (price of ticket). Indicator 28 (comfort level). Indicator 30 (helpfulness nature).

After knowing those attributes and classify them into satisfactory and not satisfactory, this assessment becomes important points for improvement and development. The next step is assessing the results of each variable analysis, which will reflect the variable position in general based on the value of the attribute. Figure 3 in below are the results of the analysis: 


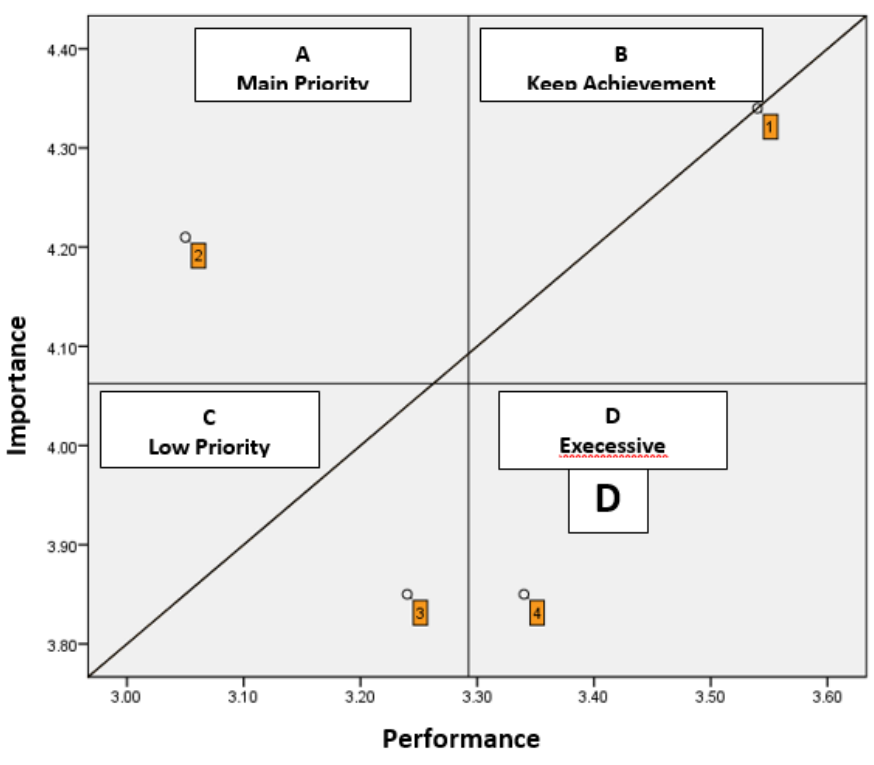

Source: Data processed in 2019

Fig. 3. Variable analysis result.

The result analysis of each variable can be explained as follow:

- Quadrant A: Variable 2 (facilities and infrastructure) are still below the visitors' expectancy. Thus, the management should improve the facilities and infrastructure including toilet quality and quantity, clean water and rubbish bins, health facilities and other facilities to fulfill their needs, ATM machines and entertainment facilities.

- Quadrant B: Variable 1 (tourism attraction) shows that the Pasir Padi Beach has a very good attraction. Thus the nature potential, as well as the wide coastal line, calm waves and white sand.

- Quadrant C: Variable 3 (management) is still poor and far below the visitors' expectancy. Therefore, the management should improve the facilities and infrastructure, tourism object management and attraction. They also have to motivate the local people to participate in the program, hold an art and cultural event or entertainment. There should be interconnected transportation to Semujur Island located in front of Pasir Padi Beach.

- Quadrant D: Variable 4 (community condition). The people of Bangka Belitung Island are very friendly and willing to support a successful tourism development in order to give satisfaction for the visitors.

\section{Gap Analysis}

Based the gap analysis, generally there are gaps. The one should be the main focus is the one with gap value of 1 (one), which means the disparity between reality and expectancy is very high. It reflects the dissatisfaction to the service or facilities offered by the management. Thus, it is highly recommended to improve the variables as follow:

- Tourism attraction variable has gap value of -0.78 , meaning in general that variable is good enough. However, the gap value for sea water quality is -1.96 and -1.14 indicating that the water and sand quality is very poor. The tailing (residue of tin mining) and mud make the water turbid. The main factor of that poor water quality is the active marine mining that is relatively near from the coastal line.

- Facilities and infrastructure variable has gap value of 0.95; meaning that variable is poor. There are five indicators that have high gap value. They are as follows: transportation to the object with gap value -1.39 , due there is no transportation means directed to the location; the indicator of shower facility and clean water with gap value -1.36; quality and quantity of toilet with gap value -2.18 due to the cleanliness is poor and there is only one shower facility made of plank; indicator of rubbish bin availability with gap value -1.98 due to the number is still limited and not accessible from the location; indicator of information service with gap value -1.11 , which is regarded poor due to the service does not function well.

- Management variable has gap value of -0.63 , which is considered poor. As you can see, the information service and cleanliness gap value is above 1 that should be prioritized in improvement. The road direction, public facility, general information, promotion as well as activities are still limited. The cleanliness quality still poor due to the number rubbish bin is still limited. However, ticketing is considered has good performance, since there is no charge for entrance. There is only retribution fee as much as Rp. 4.000 for cars and Rp. 2.000 for motorcycle, which is considered very affordable.

- Community condition variable is considered good. However, the people's awareness to the environment is still poor. It is indicated by many litters and rubbish around the beach, due to the traders do not provide rubbish bin around their small shops and the visitors' awareness to the cleanliness is also poor.

Based on the results, this research is along with the research carried out by Xue Ming Zhang who innovates and optimizes the structure of tourism product, adjust the personalized tourism development, and help to fulfill various visitors' need, open the potential tourism market and develop a new point for tourism. To fulfill the visitor's need, there should be improvement in the poor variable and development in the weak potential in Pasir Padi Beach.

\section{CONCLUSIONS AND RECOMMENDATIONS}

\section{A. Conclusions}

The Pasir Padi Beach is a very popular destination for local visitors and very accessible for national visitors, since the location is very strategic. It is near from Deapti Amir Port and the entrance is from Pangkalpinang that is the capital of Bangka Belitung Province. Since it is the main gate to Bangka Island, making the Pasir Padi Beach have a very great potential to be developed as a main destination.

Based on the descriptive analysis, the probability of local visitors probably to re-visit the object is very high. The new visitors from the national area are also significant. Their motive is generally to spend their leisure time. Most of the national 
visitors know Bangka Belitung Island as the tin mining location. Nevertheless, Bangka Belitung Island is well-known as a national or even international destination.

Based on the combined analysis between Importance Performance Analysis and gap analysis, the main priorities for improvement and development in Pasir Padi Beach are facilities and infrastructure variable. There are nine indicators including the sea water quality, transportation, clean water and shower facility, toilet quality and quantity, rubbish bin, cleanliness quality, environment awareness, sand quality as well as information service that should be improved. There is only one indicator that is considered good, which is ticketing and retribution fee. It indicates that the charge is very affordable, which needs to be adjusted in the future.

\section{B. Recommendation}

Considering the provability of revisit and number of new visitors coming to the destination, thus the facility and infrastructure should be the main priority to be improved. Some of facilities are toilet, rubbish bin and financial facility such as ATM machine and other facilities for traders. To keep the environment clean, there should be call to the local people to be environmentally aware. There should be a program to improve their capacity in supporting the Pasir Padi Beach development. As for the program itself, it can be in forms of art and cultural events, national or even international sport event, which are supported with an effective promotion. Regarding the fund, we cannot depend only on the regional government, we also should involve investors and evaluate the entrance fee to the Pasir Padi Beach, since it is still free.

\section{ACKNOWLEDGMENTS}

We would like to say gratitude to KEMRISTEK DIKTI (Ministry of Research, Technology and Higher Education) who funds this research through grant for the university lecturers and to the LPPM (Lembaga Penelitian dan Pengabdian Kepada Masyarakat or Institute for Research and Community Service) of Bangka Belitung University who have facilitated us. We would also like to be gratitude to Sandy Pratama dan Faisal Akbar and all surveyors who have helped us much in carrying out this research.

\section{REFERENCES}

[1] Ilmu Pengetahuan Umum, 2019, [online] Retrieved from: https://ilmupengetahuanumum.com/10-negara-penghasil-timah-terbesardi-dunia/.

[2] F. Razak, B.O.L. Suzana and G.H. Kapantow, "Strategi Pengembangan Wisata Bahari Pantai Malalayang, Kota Manado, Sulawesi Utara," AgriSosioekonomi: Jurnal Ilmiah Sosial Ekonomi Pertanian, vol. 13, no. 1A, pp. 277-284, 2017

[3] Wikipedia, Pantai pasir Padi, 2017 [Online]. Retrieved from: https://id.wikipedia.org/wiki/Pantai_Pasir_Padi/.

[4] D. Siagian, Teknik Sampling. Jakarta: PT. Gramedia Pustaka Utama, 2003.

[5] Sugiyono, Metode Penelitian Kombinasi (Mixed Methods). Bandung: CV Alfabeta, 2016.

[6] T. Wijayanti, M. Hubeis and M. Muksin, "Marketing Strategies For Developing Agrotourism In Jember Regency," Indonesian Journal Of Business And Entrepreneurship (IJBE), vol. 1, no. 3, pp. 148, 2015.

[7] S. Ivan, "Importance-performance analysis: A valid management tool?," Tourism Management, vol. 48, pp. 43-53, 2015.

[8] K.W.L. Ivan and H. Michael, "Importance-performance analysis in tourism: A framework for researchers,Journal Tourism Management," Vol. 48, pp. 242-267, 2015.

[9] X.Z. Xue, "Research on the Development Strategies of Rural Tourism in Suzhou Based on SWOT Analysis," Energy Procedia,Volume 16, Part B,Pages 1295-1299, ISSN 1876-6102, 2012. 